\title{
Feeding ecology of Tropidurus torquatus (Wied) (Squamata, Tropiduridae) in two areas with different degrees of conservation in Marambaia Island, Rio de Janeiro, Southeastern Brazil
}

\author{
André L. G. de Carvalho; Hélio R. da Silva; Alexandre F. B. de Araújo; \\ Ricardo Alves-Silva \& Roberta R. da Silva-Leite
}

Laboratório de Herpetologia, Departamento de Biologia Animal, Instituto de Biologia, Universidade Federal Rural do Rio de Janeiro. Rodovia BR 465, km 47, Caixa Postal 74524, 23851-970 Seropédica, Rio de Janeiro, Brasil.

E-mail: andreluizherpeto@gmail.com; helio@ufrrj.br; araujo@ufrrj.br; biologiaricardo@yahoo.com.br; robertarsl@gmail.com

\begin{abstract}
We compared the effects of habitat disturbance on the feeding ecology of two local populations of Tropidurus torquatus (Wied, 1820) in restinga habitats on Ilha da Marambaia, Southeastern Brazil. Both populations presented a relatively diverse diet and differ in the number $\left(D_{\text {Max }}=0.22, D F=2, p=0.00\right)$ and volume of prey consumed $\left(D_{\operatorname{Max}}=0.82, D F=2, p=0.00\right)$. Ants were the most frequent and numerous preys in both areas, and plant matter and coleopterans were the most important alimentary items in volume. The population from the disturbed area presented a larger niche breadth for number of prey items consumed $\left(\mathrm{Bi}_{\text {num }}=3.06\right)$ and volume $\left(B \mathrm{i}_{\mathrm{vol}}=2.98\right)$, when compared to the other population $\left(\mathrm{Bj}_{\text {num }}=2.44, \mathrm{Bj}_{\mathrm{vol}}=1.52\right)$. Niche overlap was higher for number of items consumed between the populations $\left(\mathrm{Oij}_{\text {num }}=0.82\right)$ but lower for volume $\left(\mathrm{Oij}_{\mathrm{vol}}=0.05\right)$. Our data suggest dietary differences between the two lizard populations, and these differences may be associated with environmental modifications. Our main hypothesis to explain the dietary differences is based in the Optimal Foraging Theory. However, the alimentary behavior, and consequently the diet of these lizards, seems to be constrained phylogenetically, with a pattern that may have evolved in the ancestor of all iguanids. KEY WORDS. Diet; lizards; Optimal Foraging Theory.
\end{abstract}

RESUMO. Ecologia Alimentar de Tropidurus torquatus (Wied) (Sauria, Tropiduridae) em Duas Áreas com Diferentes Níveis de Conservação na Ilha da Marambaia, Rio de Janeiro, Sudeste do Brasil. Comparamos os efeitos da degradação ambiental sobre a ecologia alimentar de duas populações de Tropidurus torquatus (Wied, 1820) em áreas de restinga da Ilha da Marambaia, sudeste do Brasil. Ambas as populações apresentaram dieta relativamente diversa e deferiram em número $\left(D_{\operatorname{Max}}=0,22 ; D F=2 ; p=0,00\right)$ e volume de presas consumidas $\left(D_{\text {Max }}=0,82 ; D F\right.$ $=2 ; \mathrm{p}=0,00$ ). Formigas foram os itens mais freqüentes e numerosos em ambas as áreas, e material vegetal $\mathrm{e}$ coleópteros os mais importantes em volume. A população da área perturbada apresentou maior largura de nicho alimentar para número de presas consumidas $\left(\mathrm{Bi}_{\text {num }}=3,06\right)$ e volume $\left(\mathrm{Bi}_{\text {vol }}=2,98\right)$, quando comparada à outra população $\left(B \mathrm{j}_{\text {num }}=2,44 ; \mathrm{Bj}_{\mathrm{vol}}=1,52\right)$. A sobreposição de nicho foi mais marcante para o número de itens consumidos entre as populações $\left(\mathrm{Oij}_{\text {num }}=0,82\right)$ e menos marcante para volume $\left(\mathrm{Oij}_{\mathrm{vol}}=0,05\right)$. Nossos dados sugerem diferenças nas dietas entre as duas populações de lagartos, e estas diferenças parecem estar associadas à degradação ambiental. Nossa principal hipótese para explicar as diferenças nas dietas embasa-se na Teoria do Forrageamento Ótimo. Entretanto, o comportamento alimentar, e conseqüentemente a dieta dos lagartos, mostrarem-se limitadas filogeneticamente, com um padrão que pode ter evoluído no ancestral de todos os iguanídeos.

PALAVRAS-CHAVE. Dieta; lagartos; Teoria do Forrageamento Ótimo.

The diet of any species is related to aspects of the local ecology of its populations as well as the evolutionary history of the taxon. Lizards present alimentary patterns well defined and constrained by their phylogeny (VITT et al. 2003, VITT \& PiANKA 2005). Two widely recognized main feeding strategies define these patterns: "widely" versus "sit-and-wait foragers"
(Huey \& PiAnKa 1981). Examples of the first strategy are lizards of the genus Ameiva Meyer, 1795 and Cnemidophorus Wagler, 1830, which seek food by actively probing the leaf litter with their tongue (Araujo 1991, Zaluar \& Rocha 2000, Rocha et al. 2000). The Tropidurid genus Tropidurus Wied-Neuwied, 1825 is a good example of the sit-and-wait strategy. This speciouse 
genus of open formations dwellers found in tropical and subtropical South America, including the Galapagos Islands (Rodrigues 1987, Lopes et al. 1992, Frost et al. 2001), presents several adaptations related to this strategy, such as criptical coloration, robust body, territorial behavior, and diet based on mobile prey (RAnd \& RAND 1966, Rodrigues 1987, Bergalo \& Rocha 1994). In Brazil, Tropidurus is present in the Amazon, Cerrado, Caatinga and Atlantic Forest, including the coastal Restingas (Rodrigues 1987, Rocha 2000).

Tropidurus torquatus (Wied, 1820) is the most widely distributed lizard in the genus, occurring from Southeastern Brazil to the north of Argentina (RODRIGUES 1987). Its diet is based on highly vagile arthropods, primarily ants, and vegetal matter, especially fruits (Araújo 1991, Rocha \& Bergalo 1994, Fialmo et al. 2000). Several aspects of its diet, foraging mode, and behavioral ecology were studied (RAND \& RAND 1966, Bergalo \& Rocha 1994, Teixeira \& GiovanelLi 1999, Rocha et al. 2000). However, the effects of environmental modifications to its feeding ecology have not been considered yet.

Changes in the environmental conditions can affect prey offer, patterns of diet, and costs of foraging. According to the Optimal Foraging Theory (MACARTHUR \& PIANKA 1966), lizards from species-rich feeding areas would present narrower food niche breadth, while lizards from areas with less dense and less nutritive prey would present larger alimentary niche breadth in order to compensate for the low quality of the prey (MacArthur \& Pianka 1966, Schoener 1971). Consequently, lizards living in a stressed environment would reduce their spatial niche to use only the best patches (MacArthur \& Pianka 1966). Therein, we tested this assumption by comparing the effects of habitat disturbance on the feeding ecology of two local populations of Tropidurus torquatus that occur in restinga habitats on Ilha da Marambaia, Rio de Janeiro, Southeastern Brazil, one preserved, and the other disturbed.

\section{MATERIAL AND METHODS}

This work was developed on Ilha da Marambaia, located in Rio de Janeiro, Southeastern Brazil (2304'S, 435' W). Marambaia presents a marked spatial heterogeneity, including rain forests on the hills (Atlantic Forest), restinga (long sand bars connecting the hills to the continent, covered with open vegetation), and mangrove (Menezes \& Araujo 2005). Two sites in the restinga habitat with different degrees of conservation were chosen for sampling the lizards (Fig. 1). The first, called Bravomeia (23004'16.36"S, 4356'43.43"W) presents a well-preserved mosaic of shrubs. The other, called Heliporto (23003'40.50"S, $43059^{\prime} 24.47$ 'W) is a small and isolated restinga area, bordered by secondary forest outgrow, both deforested and burned periodically; trash is also dumped in the area by residents.

Fieldwork was undertaken from February 2003 to September 2004. The diets were compared analyzing stomach contents. We collected 37 specimens from Heliporto and 32 from Bravo-meia, totalizing 69 lizards. The animals were euthanized

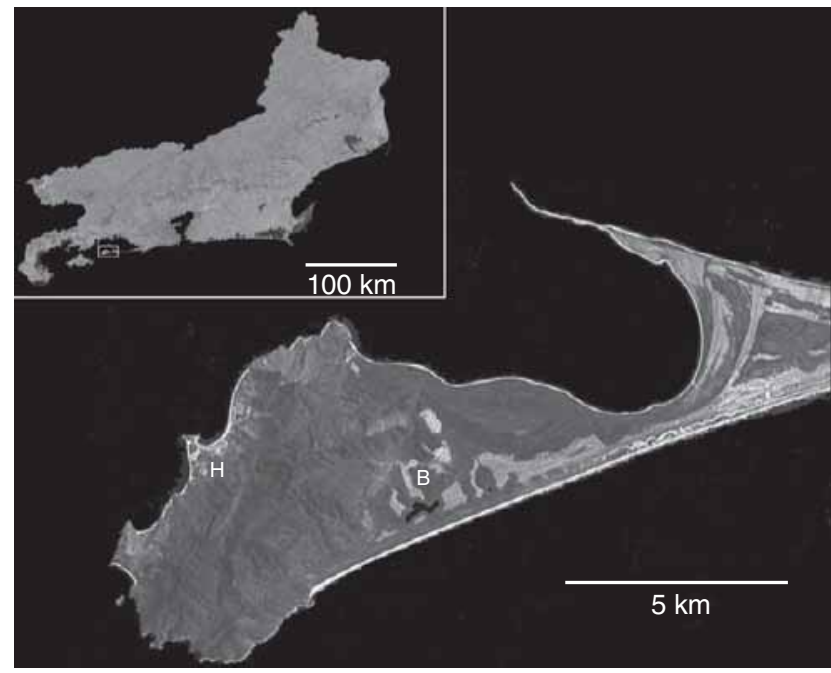

Figure 1. Map of the State of Rio de Janeiro, with the location of Marambaia (square). Enlarged, Marambaia Island with part of the restinga and indication of study areas: $(\mathrm{H})$ Heliporto, (B) Bravo-meia.

with an overdose of lidocain $0,5 \%$ and fixed in formalin $10 \%$ while in the field. The collected lizards were posterior sexed and measured (snout-vent-length) in laboratory. The animals were then dissected for the investigation of the stomach contents, using a stereomicroscope. All alimentary items were counted and measured with a caliper (length and breadth, \pm $0.05 \mathrm{~mm}$ ). The volume of the alimentary items were estimated through the ellipsoid formula (Colli et al. 1992).

$$
\text { Volume }=\frac{\left(\pi \text {. length. width }{ }^{2}\right)}{6}
$$

We calculated the alimentary niche breadth for number of items and volume consumed, for the two areas, following PiAnKa (1973). Where $P$ is the proportional utilization of the prey item $\mathrm{i}$ and $\mathrm{n}$ is the number of prey categories used.

$$
B=\frac{1}{\sum_{i=1}^{n} P_{i}^{2}}
$$

To evaluate the similarity between the diets of the two lizard populations, we used the niche overlap index (PIANKA 1973), symbols the same as above, but $\mathrm{j}$ and $\mathrm{k}$ represent each lizard population.

$$
\phi_{j}=\frac{\sum_{n=1} P_{i j} P_{i k}}{\sqrt{\sum_{i=1}^{n} P_{i j}^{2} \sum_{i=1}^{n} P_{i k}^{2}}}
$$

We tested differences in size between the two lizard's

Revista Brasileira de Zoologia 24 (1): 222-227, março 2007 
populations using the T Test. Diet differences were tested using Kolmorogov-Smirnov. The Z Test was performed to evaluate differences in the consumption (number and volume) of each prey category separately. To evaluate differences in the mean number, size and volume of prey items consumed in the two areas, we used the Mann-Whitney Test. The relationship between the snout-vent-length (SVL) and number and volume of prey items consumed was evaluated using linear regression analysis. The statistical methodology followed ZAR (1999).

\section{RESULTS}

According to $T$ Test, the two lizard populations do not differ in size $(T=0.33$, $D F=67, p=0.74)$. Both populations presented a relatively diverse diet, with 19 prey categories consumed by the population from Bravo-meia and 18 prey categories consumed by the population from Heliporto. However, just 15 prey categories are common to both populations (Tab. I). Despitethesimilarity in the number of prey categories consumed, the populations differed in number (Kolmogorov-Smirnov, $D_{\text {Max }}$ $=0.22$, DF $=2, p=0.00$ ) and volume of preys consumed (Kolmogorov-Smirnov, $\mathrm{D}_{\text {Max }}=0.82, \mathrm{DF}=2, \mathrm{p}=0.00$ ). Ants were the most frequent and numerous prey items in both areas. Volumetrically, vegetal matter was the most important alimentary category for the population from Bravo-meia, whilefor Heliporto it was Coleoptera (Tab. I). The Z Test indicated differences in the proportion of volume consumed for the majority of prey items and to half of them, in numerical proportion (Tab. II). Similarity in thenumerical consumption of the prey items was observed just for those less-consumed categories.

The population from Heliporto presented a larger niche breadth for number of prey items consumed $\left(\mathrm{Bi}_{\text {num }}=3.06\right)$ and volume $\left(\mathrm{Bi}_{\text {vol }}=2.98\right)$ while the population from Bravo-meia presented lower values $\left(\mathrm{Bj}_{\text {num }}=2.441, \mathrm{Bj}_{\text {vol }}=1.52\right)$. The niche overlap was superior for number of items consumed between the populations $\left(\mathrm{Oij}_{\text {num }}=0.82\right)$ and lower for volume $\left(\mathrm{Oij}_{\mathrm{vol}}=0.05\right)$.

The results of the Mann-Whitney Test indicated that the mean number $\left(U=525.50, \chi^{2}=0.64\right.$, $\left.D F=1, p=0.42\right)$, mean size $\left(U=444.00, \chi^{2}=3.17, D F=1, p=0.07\right)$ and mean volume $\left(U=610.00, \chi^{2}=0.05, D F=1, p=0.83\right)$ of prey items consumed by the lizards from the two areas were not statistically different.

The linear regression analysis indicated no relationship between body size and number (Heliporto: $r^{2}=0.01, F=0.22, p$

Table I. Number of items, volume $\left(\mathrm{mm}^{3}\right)$ and frequency of each prey consumed by the two populations of Tropidurus torquatus studied on Illha da Marambaia, Rio de Janeiro.

\begin{tabular}{|c|c|c|c|c|c|c|}
\hline \multirow{2}{*}{ Prey } & \multicolumn{2}{|c|}{ Bravo-meia $(n=32)$} & \multirow[b]{2}{*}{ Frequency } & \multicolumn{3}{|c|}{ Heliporto $(n=37)$} \\
\hline & Items (\%) & Volume (\%) & & Items (\%) & Volume (\%) & Frequency \\
\hline Acarina & $1(0.002)$ & $4.81(\lessdot 0.001)$ & 0.03 & - & - & - \\
\hline Aranae & $8(0.015)$ & $1621.91 \quad(0.044)$ & 0.19 & $5(0.005)$ & $113.48 \quad(0.005)$ & 0.11 \\
\hline Blattaria & $8(0.015)$ & $635.07 \quad(0.017)$ & 0.16 & $6(0.006)$ & $344.48 \quad(0.014)$ & 0.11 \\
\hline Chilopoda & $2(0.003)$ & $93.54 \quad(0.002)$ & 0.03 & $2(0.002)$ & $44.71 \quad(0.002)$ & 0.05 \\
\hline Coleoptera & $18(0.034)$ & $326.81 \quad(0.009)$ & 0.34 & $61(0.064)$ & $13382.06 \quad(0.550)$ & 0.59 \\
\hline Diplopoda & - & - & - & $1(0.001)$ & $83.73 \quad(0.003)$ & 0.03 \\
\hline Diptera & $11(0.020)$ & $93.26 \quad(0.002)$ & 0.03 & $3(0.003)$ & $112.90 \quad(0.005)$ & 0.08 \\
\hline Egg & - & - & - & $1(0.001)$ & $32.66 \quad(0.001)$ & 0.03 \\
\hline Formicidae & $332(0.622)$ & $1107.91 \quad(0.030)$ & 0.84 & 389 (0.409) & $2895.87 \quad(0.119)$ & 0.89 \\
\hline Gastropoda & $1(0.002)$ & $3.39(\varangle 0.001)$ & 0.03 & $2(0.002)$ & $6.40(\varangle 0.001)$ & 0.05 \\
\hline Hemiptera & $2(0.004)$ & $8.70(\varangle 0.001)$ & 0.06 & $16(0.017)$ & $1180.99 \quad(0.048)$ & 0.27 \\
\hline Homoptera & $2(0.004)$ & $52.86(0.001)$ & 0.06 & $5(0.005)$ & $1156.85 \quad(0.047)$ & 0.11 \\
\hline Hymenoptera & $24(0.045)$ & $1187.35 \quad(0.032)$ & 0.28 & $44(0.046)$ & $1065.37 \quad(0.044)$ & 0.46 \\
\hline Isopoda & - & - & - & $8(0.008)$ & $212.93 \quad(0.009)$ & 0.13 \\
\hline Isoptera & $59(0.110)$ & $87.75 \quad(0.002)$ & 0.12 & $371(0.390)$ & $867.78 \quad(0.036)$ & 0.30 \\
\hline Larva & $9(0.017)$ & $844.11 \quad(0.023)$ & 0.18 & $30(0.031)$ & $2494.52 \quad(0.102)$ & 0.40 \\
\hline Mantodea & $1(0.002)$ & $29.44(\varangle 0.001)$ & 0.03 & - & - & - \\
\hline Neuroptera & $1(0.002)$ & $49.06 \quad(0.001)$ & 0.03 & - & - & - \\
\hline Odonata & $1(0.002)$ & $4.24(\varangle 0.001)$ & 0.03 & - & - & - \\
\hline Orthoptera & $11(0.021)$ & $901.96 \quad(0.024)$ & 0.31 & $2(0.002)$ & $35.02 \quad(0.001)$ & 0.05 \\
\hline Scorpiones & $1(0.002)$ & $13.84(\varangle 0.001)$ & 0.03 & $1(0.001)$ & $0.46(\varangle 0.001)$ & 0.03 \\
\hline Vegetal matter & $42(0.079)$ & $29603.81 \quad(0.807)$ & 0.59 & $5(0.005)$ & $312.36 \quad(0.001)$ & 0.13 \\
\hline Total & 534 & 36669.83 & & 952 & 24342.62 & \\
\hline
\end{tabular}

Revista Brasileira de Zoologia 24 (1): 222-227, março 2007 
$=0.64$ - Bravo-meia: $r^{2}=0.02, F=0.52, p=0.48$ ) or volume (Heliporto: $r^{2}=0.09, F=0.78, p=0.38$ - Bravo-meia: $r^{2}=0.09$, $\mathrm{F}=3.05, \mathrm{p}=0.09$ ) of prey items consumed.

Table II. Results of the $Z$ Test for differences in the proportion of consumption (number and volume) of each prey category used by the two populations of Tropidurus torquatus studied on Ilha da Marambaia, Rio de Janeiro. Significant $p$ values are in bold face.

\begin{tabular}{|c|c|c|c|c|}
\hline \multirow{2}{*}{ Taxon } & \multicolumn{2}{|c|}{ Number of items } & \multicolumn{2}{|c|}{ Volume } \\
\hline & $Z$ & $P$ & $Z$ & $P$ \\
\hline Acarina & 1.336 & 0.091 & 1.630 & 0.052 \\
\hline Aranae & 1.932 & 0.027 & 28.798 & 0.000 \\
\hline Blattaria & 1.662 & 0.048 & 3.066 & 0.001 \\
\hline Chilopoda & 0.587 & 0.279 & 1.862 & 0.031 \\
\hline Coleoptera & -2.504 & 0.006 & 0.000 & 0.000 \\
\hline Diplopoda & -0.749 & 0.227 & -11.189 & 0.000 \\
\hline Diptera & 3.341 & 0.000 & -4.316 & 0.000 \\
\hline Egg & -0.749 & 0.227 & -6.945 & 0.000 \\
\hline Formicidae & 7.887 & 0.000 & -43.356 & 0.000 \\
\hline Gastropoda & -0.094 & 0.462 & -1.640 & 0.050 \\
\hline Hemiptera & -2.208 & 0.014 & -42.243 & 0.000 \\
\hline Homoptera & -0.407 & 0.342 & -40.001 & 0.000 \\
\hline Hymenoptera & -0.113 & 0.455 & -7.301 & 0.000 \\
\hline Isopoda & -2.124 & 0.017 & -17.902 & 0.000 \\
\hline Isoptera & -11.389 & 0.000 & -32.412 & 0.000 \\
\hline Larva & -1.696 & 0.045 & -42.251 & 0.000 \\
\hline Mantodea & 1.336 & 0.091 & 3.489 & 0.000 \\
\hline Neuroptera & 1.336 & 0.091 & 5.155 & 0.000 \\
\hline Odonata & 1.336 & 0.091 & 1.630 & 0.052 \\
\hline Orthoptera & 3.674 & 0.000 & 22.766 & 0.000 \\
\hline Scorpiones & 0.415 & 0.339 & 2.938 & 0.002 \\
\hline Vegetal matter & 5.472 & 0.000 & 192.230 & 0.000 \\
\hline
\end{tabular}

\section{DISCUSSION}

Our data suggest dietary differences between the two lizard populations. Given that lizards from the two populations do not differ in size, these differences may be associated with environmental differences between the two areas and not to morfometrical differences between the populations. Our main hypothesis to explain the dietary differences is based in the Optimal Foraging Theory (MacArthur \& Pianka 1966, Schoener 1971). According to this theory, as prey offer (and quality) de teriorates in a given area, the alimentary niche breadth is enlarged (MACARTHUR \& PIANKA 1966).

The values for alimentary niche breadth found for the two lizard populations support these assumptions. Lizards from the disturbed area (Heliporto) presented larger alimentary niche breadth, indicating a more generalist diet. However, the total number of prey categories consumed was similar for the two populations, with 15 (out of 22) items in common, indicating that, in general, diets were not radically different. The high consumption of ants by the two populations, for example, re inforce a well-known pattern of item consumption among tropidurids, that are sit-and-wait lizards (HuEY \& PIANKA 1981) and present diet dominated by some common mobile items like ants (VITT et al. 2003, VITT \& PIANKa 2005).

Several works report large usage of ants by sit-and-wait lizards, especially among Tropidurus. The consumption of ants is extremely common in species of different habitats and localities. Good examples of the frequency of this behavior are T. oreadicus Rodrigues, 1987 (Araujo 1987, Faria \& Araujo 2004), T. itambere Rodrigues, 1987 (VAn-SLuYs 1993, FarIa \& Araujo 2004), and T. spinulosus (Cope, 1862) (Colu et al. 1992) from Brazilian Cerrado; T. hispidus (Spix, 1825) (VITT et al. 1996) in isolated rock outcrops in Amazonia; or T. melanopleurus Boulenger, 1902, an Andean species (Perez-Mellado \& De-la-Riva 1993). The tropidurid genus Liolaemus Wiegmann, 1834 is another example of a similar dietary pattern. L. lutzae Mertens, 1938, a sand dune lizard of coastal formations from Rio de Janeiro, Brazil, in addition to high consumption of vegetal matter, uses insect larva, coleopterans, and ants in large amounts (RochA 1989).

The amount of vegetal matter consumed was notably altered, being lower in Heliporto when compared to Bravo-meia. These results suggest that modifications in the local flora caused by burn, deforestation, and soil overturn may affect the diet of the lizards by altering the availability of items. Tropidurus torquatus is known for its consumption of vegetal matter (Teixeira \& Giovanelli 1999, Fialho et al. 2000). In Maricá, another area of restinga in Rio de Janeiro, FiALHo et al. (2000) documented high utilization of fruits by this species. Fruits of Erythroxylon ovalifolium Peyritisch, 1879 (Erythroxylaceae) represented about $50 \%$ of the diet of adult males sampled during the summer, the peak of this plant's fruit-bearing season.

FialHo et al. (2000) also showed that vegetal matter consumption was positively correlated to the body size of the lizards, pointing to an increase of herbivory during lizard growth. Considering the significant use of plants reported for Tropidurus torquatus, and confirmed in this work for the lizards from the more intact restinga area, we can suppose that changes in the composition of plants may have been caused by environmental disturbances - changing or depressing the offer of eatable fruits, leaves and flowers - and that it may have affected the lizard's diet, perhaps altering ontogenetic feeding preferences. The importance of vegetal matter in the diet of the Tropidurus is reinforced by analyzing the niche overlap value for volume. The low value obtained indicates that vegetal matter is volumetrically one of the most important items, differing sensitively in the diet of the two Tropidurus populations studied.

Our results also indicate that besides the depression of herbivory, changes in the frequency of consumption of some 
A. L. G. de Carvalho et al.

other items were recorded in the disturbed area. It is possible that these events are associated. Therefore, in order to compensate for the reduction of vegetal matter in the diet, the lizards apparently substitute other items in higher frequency, for example coleopterans, as registered for the population from Heliporto. Despite some differences regarding prey items in the diet of the two populations, the common prey do not differ in size or volume, indicating that the disturbed area, in general, sustains a similar supply of arthropods that possibly differ in frequency, as observed in the stomach contents of the lizards.

Another hypothesis that can account for the differences in the frequency of consumption of different groups of arthropods among the two areas relates to the possibility of incoming and/or increasing of some arthropod populations that would not be present, or in high density, in the area under normal, undisturbed, conditions. Unfortunately, during the fieldwork, samples of the available arthropods were not taken. Therefore, we cannot properly evaluate this hypothesis.

In addition to the aforementioned, in Heliporto, the lizards are commonly observed visiting the forested area near the restinga, using trunks and branches as perches for thermoregulation, and possibly as foraging sites. The use of this boundary may be reflected in the diet of the lizards from Heliporto.

No relationship between lizards body size and prey number and volume were observed in both areas studied, contrary to what was expected according the Optimal Foraging Theory (MacArthur \& Pianka 1966, Schoener 1971). This theory predicts that an optimal prey size would be consumed with reduced time of prey handling by the predator. However, it is possible that this expected effect on generalist lizards like Tropidurus torquatus is less strong than in more specialized ones; however, this will require further investigation.

In summary, analysis of the stomach contents in addition to consideration of lizards as good samplers of the food offer, the data indicate that environmental modifications may affect the feeding habits of Tropidurus torquatus, especially in plant consumption, as predicted by the Optimal Foraging Theory. The availability of prey items needs to be measured in future studies. Overall, however, the dietary pattern of this lizard species seems to be conservative, following a diet phylogenetically determined perhaps in the common ancestor of all iguanids (VITT et al. 2003, VITT \& PIANKA 2005), since this behavior has been observed even in altered conditions.

\section{ACKNOWLEDGEMENTS}

To the Brazilian Navy, in special the command of CADIM (Centro de Adestramento da Ilha da Marambaia), that allowed us to access the Island of Marambaia and use some of the facilities of CADIM during field work and to CNPq (The National Council for Scientific and Technological Development) by the Scientific Inciation Fellowship given to ALGC and by the Grant 471081/2004-3 given to HRS. Mary S. Linn (University of Oklahoma) for reviewing the manuscript.

Revista Brasileira de Zoologia 24 (1): 222-227, março 2007

\section{REFERENCES}

Araújo, A.F.B. 1987. Comportamento Alimentar dos Lagartos: O Caso dos Tropidurus do Grupo torquatus da Serra de Carajás, Pará (Sauria: Iguanidade). Anais de Etologia 5: 203-234.

Araújo, A.F.B. 1991. Structure of a White Sand-dune lizard community of coastal Brazil. Revista Brasileira de Biologia 54 (4): 857-865.

Bergallo, H.G. \& C.F.D. Rocha. 1994. Spatial and Trophic Niche Differentiation in Two Sympatric Lizards (Tropidurus torquatus and Cnemidophorus ocellifer) with Different Foraging Tactics. Australian Journal of Ecology 19: 72-75.

Colli, G.R; A.F.B. Araújo; R. Silveira \& F. Roma. 1992. Niche Partitioning and M orphology of Two Syntopic Tropidurus (Sauria: Tropiduridae) in Mato Grosso, Brazil. Journal of Herpetology 26: 66-69.

Faria, R.G. \& A.F.B. Araújo. 2004. Sintopy of Two Tropidurus Lizard Species (Squamata: Tropiduridae) in a Rocky Cerrado Habitat in Central Brazil. Brazilian Journal of Biology 64 (4): 775-786.

FialHo, R.F.; C.F.D. Rocha \& D. VRCIBRADIC. 2000. Feeding Ecology of Tropidurus torquatus: Ontogenetic Shift in Plant Consumption and Seasonal Trends in Diet. Journal of Herpetology 34: 325-330.

Frost, D.R.; M.T. Rodrigues; T. Grant \& T.A. Titus. 2001. Phylogenetics of the Lizard Genus Tropidurus (Squamata: Tropiduridae: Tropidurinae): Direct Optimization, Descriptive Efficiency, and Sensitivity Analysis of Congruence Between Molecular Data and Morphology. Molecular Phylogenetics and Evolution 21: 352-371.

Huey, R.B. \& E.R. Pianka. 1981. Ecological Consequences of Foraging Mode. Ecology 62 (4): 991-999.

Lopez, T. J.; E.D. Hauselman; L.R. Maxson \& J.W. Wright. 1992. Preliminary analysis of phylogenetic relationships among Galapagos Island lizards of the genus Tropidurus. AmphibiaReptilia 13: 327-39.

MacArthur, R.H. \& E.R. Pianka. 1966. Optimal Use of a Patchy Environment. American Naturalist, Chicago, 100: 603-609.

Menezes, L.F.T. \& D.S.D. Araujo. 2005. Formações Vegetais da Restinga da Marambaia, p. 67-120. In: L.F.T. Menezes, A.L. Peixoto \& D.S.D. Araujo (Eds). História Natural da Marambaia. Seropédica, Editora da Universidade Federal Rural do Rio de Janeiro, 260p.

Perez-Mellado, V. \& I. De-La-Riva. 1993. Sexual Size Dimorphism an Ecology: The Case of a Tropical Lizard, Tropidurus melanopleurus (Sauria: Tropiduridae). Copeia 4: 969-976.

PianKA, E.R. 1973. The Structure of Lizard Communities. Annual Review of Ecology an Systematics 4: 53-74.

RAND, A.S. \& P.J. RAND. 1966. Aspects of the ecology of theiguanid lizard Tropidurus Torquartus at Belém, Pará. Smithsonian Miscellaneous Collection 115 (2): 1-16.

Rocha, C.F.D. 1989. Diet of a Tropical Lizard (Liolaemus lutzae) of Southeastern Brazil. Journal of Herpetology 23 (3): 292-294. RochA, C.F.D. 2000. Biogeografia de répteis de restingas: distri- 
buição, ocorrências e endemismos, p. 99-116. In: F.V. EsteVES \& L.D. LACERDA (Eds). Ecologia de restingas e lagoas costeiras. Macaé, NUPEN-UFRJ, 394p.

RochA, C.F.D. \& H.G. Bergalo. 1994. Tropidurus torquatus (Collared Lizard). Diet. Herpetological Review 25 (2): 69.

Rocha, C.F.D.; D. Vrcibradic \& A.F.B. Araújo. 2000. Ecofisiologia de répteis de restingas brasileiras, p. 117-149. In: F. V. ESTEVES $\&$ L. D. LACERDA (Eds). Ecologia de restingas e lagoas costeiras. Macaé, NUPEN-UFRJ, 394p.

Rodrigues, M.T. 1987. Sistemática, Ecologia e Zoogeografia dos Tropidurus do grupo torquatus ao Sul do Rio Amazonas (Sauria, Iguanidae). Arquivos de Zoologia 31 (3): 105-230.

Schoener, T.W. 1971. Theory of Feeding Strategies. Annual Review of Ecology and Systematics 2: 369-404.

Teixeira, R.L. \& M. Giovanelli. 1999. Ecologia de Tropidurus torquatus (Sauria: Tropiduridae) da Restinga de Guriri, São Mateus, ES. Revista Brasileira de Biologia 59 (1): 11-18.

VAN-SLUYS, M. 1993. Food habits of the lizard Tropidurus itambere
(Tropiduridae) in southeastern Brazil. Journal of Herpetology 27: 347-351.

VITT, L.J. \& E.R. PianKa. 2005. Deep History Impacts Presentday Ecology and Biodiversity. Proceedings of the National Academy of Sciences 102 (22): 7877-7881.

VITT, L.J.; P.A.ZANI. \& J.P. CALDWELL. 1996. Behavioural Ecology of Tropidurus hispidus on Isolated Rock Outcrops in Amazonia. Journal of Tropical Ecology 12: 81-101.

VitT, L.J.; E.R. Pianka; W.E. CoOper-J R. \& K. Schwenk. 2003. History and the Global Ecology of Squamate Reptiles. American Naturalis 162 (1): 44-60.

ZALUAR, H.L.T. \& C.F.D. RochA. 2000. Ecology of the wide-foraging lizard Ameiva ameiva (Teiidae) in a sand dune habitat of Southeast Brazil: Ontogenetic, sexual and sexual trends in food habits, activity, thermal biology, and microhabitat use. Ciência e Cultura 52 (2): 101-107.

ZAR, J.H. 1999. Biostatistical Analysis. New Jersey, Prentice Hall, $663 p$.

Received in 15.VIII.2006; accepted in 07.III.2007. 